\title{
Female adnexal tumour of probable Wolffian origin: a rare entity with challenging histopathological diagnosis and unpredictable behaviour
}

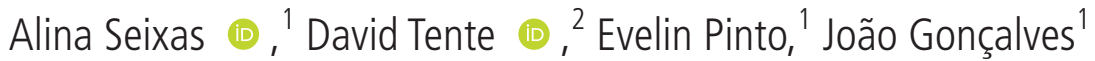

'Department of Obstetrics and Gynaecology, Centro Hospitalar de Vila Nova de Gaia/Espinho, E.P.E, Vila Nova de Gaia, Porto, Portugal

${ }^{2}$ Department of Pathology, Centro Hospitalar de Vila Nova de Gaia/Espinho, E.P.E, Vila Nova de Gaia, Porto, Portugal

\section{Correspondence to}

Dr Alina Seixas;

alina.seixas@gmail.com

Accepted 25 August 2020

Check for updates

(c) BMJ Publishing Group Limited 2020. No commercial re-use. See rights and permissions. Published by BMJ.

To cite: Seixas A, Tente $D$, Pinto $\mathrm{E}_{\text {, et al. BMJ Case }}$ Rep 2020;13:e237127. doi:10.1136/bcr-2020237127

\section{DESCRIPTION}

A 39-year-old healthy woman, gravida 2 para 2 , was referred to our gynaecological outpatient clinic after an incidental sonographic diagnosis of a right adnexal solid mass. Transvaginal ultrasound revealed an enlarged fibroid uterus and a $51 \mathrm{~mm}$ nodular paraovarian mass suggesting either a pedunculated or a broad ligament fibroid. Blood tests showed normal serum cancer markers. At that time, the patient was considering getting pregnant again. Consequently, expectant management was decided.

After 2 years, the patient no longer expressed desire to preserve fertility. On physical examination, the enlarged uterus and a solid nodular mass on the right adnexal area were palpable. On transvaginal ultrasound, the right adnexal mass appeared complex, measuring $115 \mathrm{~mm} \times 66 \mathrm{~mm}$, with both solid and cystic components, and low vascularity in colour Doppler evaluation (figure 1). Serum cancer antigen 125 (CA-125) level was $67.3 \mathrm{U} / \mathrm{mL}$.

A solid and cystic structure and increased serum CA-125 raised concern for an ovarian cancer, but hypovascularity of the solid aspects suggested a fibroid or another benign tumour, with degenerative cystic changes. In this context, an exploratory laparotomy with intraoperative pathology consultation was decided, confirming a $15 \mathrm{~cm} \times 8 \mathrm{~cm} \times 8 \mathrm{~cm}$ solid and cystic mass. The frozen section revealed a solid spindle cell pattern, favouring a fibrothecoma. Right salpingo-oophorectomy, total hysterectomy and left salpingectomy were performed. The tumour's various morphologic patterns (predominantly solid, tubular and sieve-like) and Wolffian immunophenotype were consistent with a female adnexal tumour of probable Wolffian origin (FATWO): see figure 2 for details.

After discussing management options with the patient at follow-up, and in the absence of established prognostic criteria, no further intervention was planned. The patient is clinically well (4 years post operation)

Female adnexal tumours of probable Wolffian origin, first described in 1973, presumably originate in the mesonephric (or Wolffian) duct. ${ }^{1}$ These epithelial tumours are extremely rare, with only around 100 cases published worldwide. ${ }^{2}$ FATWOs are most frequently found in the broad ligament, but can also appear in the mesosalpinx, Fallopian tube, ovary, paravaginal region or peritoneum. ${ }^{3}$ The median age at diagnosis is 50 years (range 15-87 years). ${ }^{23}$
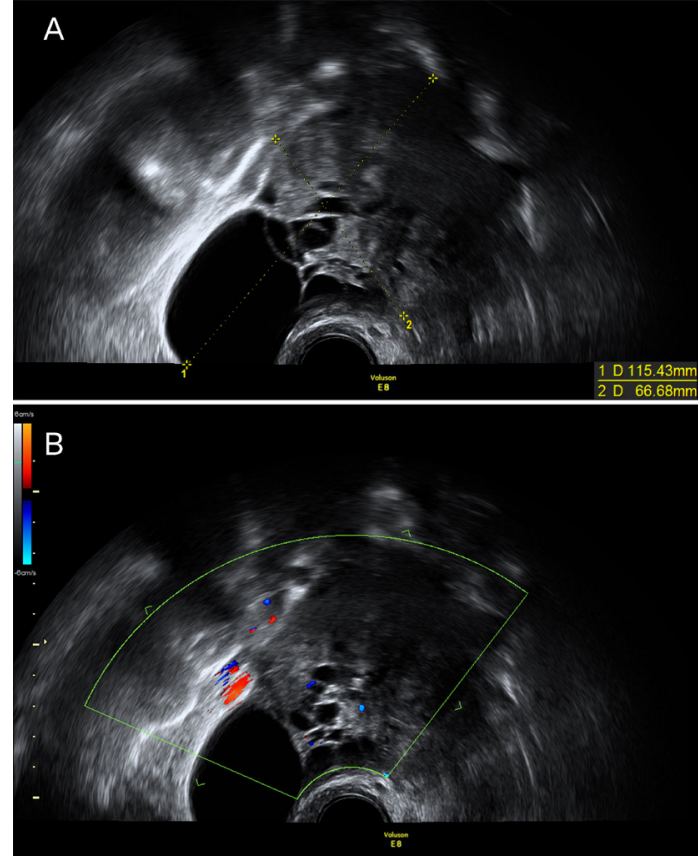

Figure 1 Transvaginal ultrasound showing a complex mass in the right adnexal area measuring $115 \mathrm{~mm} \times 66$ $\mathrm{mm}$, with both solid and cystic components $(A)$ and low vascularity in colour Doppler evaluation (B).

FATWOs can resemble ovarian endometrioid adenocarcinomas (tubular and sieve-like patterns), Sertoli-Leydig cell tumours (tubular or retiform patterns) or granulosa stromal cell tumours, namely of the fibroma-thecoma group (solid pattern), since they show variable intertumoural and intratumoural morphology (mostly solid, tubular and sieve-like). This challenging diagnosis requires thorough morphologic and immunohistochemical evaluation, since there are no typical morphologic features nor a specific immunostain. ${ }^{34}$

These tumours are usually benign, but almost one-fifth of cases show a more aggressive behaviour, with distant metastases and recurrence even long after initial diagnosis. ${ }^{5}$ Due to the rarity of this condition-and consequent scarcity of data-its prognostic factors are not clearly established. ${ }^{6}$ From the limited information available, prognosis does not seem to correlate unequivocally with either clinical presentation or histopathological features. ${ }^{3}$ Consequently, treatment is individualised. Generally, the most adequate treatment is considered to be total surgical resection, with 


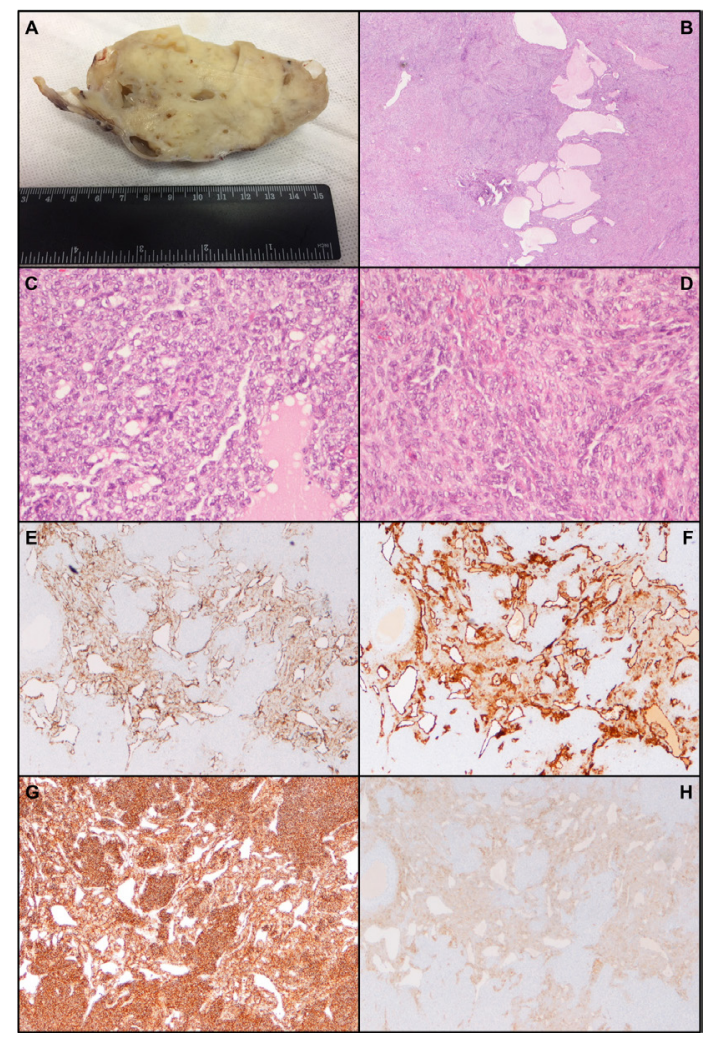

Figure 2 Predominantly solid mass, with cystic areas, yellowish cutting surface and firm consistency (A). The tumour consisted of focal cystic spaces filled with eosinophilic secretions and solid sheets of spindle or oval cells, also lining the cysts; cells had vesicular chromatin, no significant pleomorphism and absent nucleoli (B,C-haematoxylin and eosin, 40x and haematoxylin and eosin, 200x). Occasionally, a sieve-like pattern and packed tubules were found, lined by the same cell types (D-haematoxylin and eosin, 200x). The neoplastic cells were positive for keratins, highlighting areas of retiform pattern (E-Cam5.2, $40 \times)$. The cells lining the spaces were positive for calretinin and Wilms' tumour 1 (WT1) (F-calretinin, 40x). Vimentin was diffusely positive ( $G$ - vimentin, 40x) and inhibin was positive in areas surrounding the spaces ( $\mathrm{H}$-inhibin, 40x). There was no immunostaining for desmin or smooth muscle actin, nor for epithelial membrane antigen (EMA), cluster of differentiation 10 (CD10), paired box 8 (PAX8), or keratin 5 (not shown).

tumour debulking, total hysterectomy and bilateral salpingooophorectomy. ${ }^{3}$ The role of complementary treatments is controversial. ${ }^{3}$ Due to its malignant potential, regular and long-term follow-up is recommended. ${ }^{6}$

\section{Learning points}

- Female adnexal tumours of probable Wolffian origin are a rare entity that poses difficulties in terms of histopathological diagnosis and clinical management.

- Despite having a benign behaviour in most cases, they do have some malignant potential. Consequently, long-term follow-up is recommended.

- The diagnosis is extremely difficult in frozen section, given that evaluation of multiple sections and immunohistochemical studies are not possible in that context. Hence, misdiagnosis as a malignant tumour, especially endometrioid adenocarcinoma of the ovary, or as other common tumours can be a pitfall.

Acknowledgements The authors would like to thank Professor Ana Félix (Department of Pathology, Instituto Português de Oncologia de Lisboa, Lisbon, Portugal) for her contribution revising the histology slides, corroborating the final diagnosis.

Contributors AS was the main surgeon and wrote the case report. DT made the histopathological diagnosis and reviewed the manuscript. JG followed the patient in gynaecological outpatient clinic and postoperative follow-up appointments and reviewed the manuscript. EP assisted with literature review for clinical management and reviewed the manuscript.

Funding The authors have not declared a specific grant for this research from any funding agency in the public, commercial or not-for-profit sectors.

Competing interests None declared.

Patient consent for publication Obtained.

Provenance and peer review Not commissioned; externally peer reviewed.

\section{ORCID iDs}

Alina Seixas http://orcid.org/0000-0002-7064-910X

David Tente http://orcid.org/0000-0001-7623-5269

\section{REFERENCES}

1 Kariminejad MH, Scully RE. Female adnexal tumor of probable wolffian origin. A distinctive pathologic entity. Cancer 1973;31:671-7.

2 Lucas $\mathrm{E}$, Zheng W. Female adnexal tumor of probable wolffian origin (FATWO). Available: http://www.pathologyoutlines.com/topic/ovarytumorfatwo.html [Accessed 13 May 2020].

3 Shalaby A, Shenoy V. Female adnexal tumor of probable wolffian origin: a review. Arch Pathol Lab Med 2020;144:24-8.

4 Bennett JA, Ritterhouse LL, Furtado LV, et al. Female adnexal tumors of probable wolffian origin: morphological, immunohistochemical, and molecular analysis of 15 cases. Mod Pathol 2020;33:734-47.

5 Heatley MK. Is female adnexal tumour of probable wolffian origin a benign lesion? A systematic review of the English literature. Pathology 2009;41:645-8.

6 Türkçapar AF, Seçkin B, Güngör T, et al. Diagnosis and management of female adnexal tumor of probable wolffian origin (FATWO) arising from ovary: a case report. J Turk Ger Gynecol Assoc 2013;14:56-9.

Copyright 2020 BMJ Publishing Group. All rights reserved. For permission to reuse any of this content visit

https://www.bmj.com/company/products-services/rights-and-licensing/permissions/

BMJ Case Report Fellows may re-use this article for personal use and teaching without any further permission.

Become a Fellow of BMJ Case Reports today and you can:

- Submit as many cases as you like

- Enjoy fast sympathetic peer review and rapid publication of accepted articles

Access all the published articles

Re-use any of the published material for personal use and teaching without further permission

Customer Service

If you have any further queries about your subscription, please contact our customer services team on +44 (0) 2071111105 or via email at support@bmj.com.

Visit casereports.bmj.com for more articles like this and to become a Fellow 